\title{
Copper inorganic-organic hybrid coordination compound as a novel L-cysteine electrochemical sensor: Synthesis, characterization, spectroscopy and crystal structure
}

\author{
ZOHREH DERIKVAND* and AZADEH AZADBAKHT \\ Department of Chemistry, Faculty of Science, Khorramabad Branch, Islamic Azad University, \\ Khorramabad, Iran \\ e-mail: zderik@yahoo.com
}

MS received 24 May 2015; revised 27 August 2015; accepted 1 September 2015

\begin{abstract}
Dinuclear coordination compound of $\mathrm{Cu}(\mathrm{II})$, namely, $\left[\mathrm{Cu}_{2}(\text { pydc })_{2}(\mathrm{pz})\left(\mathrm{H}_{2} \mathrm{O}\right)_{2}\right] \cdot 2 \mathrm{H}_{2} \mathrm{O}$, where pydc = pyridine-2,6-dicarboxylic acid (dipicolinic acid) and pz = pyrazine has been synthesized and characterized by elemental analysis, spectra (IR, UV-Vis), thermal (TG/DTG) analysis, magnetic measurements and single crystal X-ray diffraction. In the dimeric structure, the planar tridentate pyridine-2,6-dicarboxylic acid dianion coordinates to a $\mathrm{Cu}(\mathrm{II})$ ion in a meridional fashion and defines the basal plane of the complex. The fourth equatorial coordination site is then occupied by a pyrazine molecule that functions as a linear bidentate ligand bridging two $\mathrm{Cu}$ (II) complexes to form a dimer. The axial positions of each $\mathrm{Cu}$ (II) complex are occupied by one water molecule to form a distorted square pyramidal geometry. The complicated hydrogen bonding network accompanied with $\mathrm{C}-\mathrm{O} \cdots \pi$ and $\mathrm{C}-\mathrm{H} \cdots \pi$ stacking interactions assemble the crystal structure of $\mathbf{1}$ into a fascinating supramolecular architecture. Electrochemical behavior of $\left[\mathrm{Cu}_{2}(\mathrm{pydc})_{2}(\mathrm{pz})\left(\mathrm{H}_{2} \mathrm{O}\right)_{2}\right](\mathrm{Cu}-\mathrm{PDAP})$ on the surface of carbon nanotube (CNTs) glassy carbon electrode (GCE) is described. Oxidation of cysteine on the surface of modified electrode was investigated with cyclic voltammetry and electrochemical impedance spectroscopy (EIS). The results show that the $\mathrm{Cu}$-PDAP/CNTs film displays excellent electrochemical catalytic activities towards L-cysteine oxidation.
\end{abstract}

Keywords. Pyridine-2,6-dicarboxylic acid; Crystal structure; Dinuclear complex; Electrocatalysis; Impedance spectroscopy.

\section{Introduction}

The design and construction of inorganic-organic hybrid materials attract great attention in the fields of crystal engineering and supramolecular chemistry, owing to fascinating topological architectures and powerful potential applications in various areas, such as nonlinear optics, magnetism, heterogeneous catalysis, gas storage and luminescent materials. ${ }^{1-11}$ Predicting the final structures of demanded crystalline products is a great challenge. The self-assembly process of crystalline products is influenced by various factors, such as metal salt, organic ligands, counter ions, solvent system, temperature and $\mathrm{pH}$ of the reaction system. ${ }^{12-14}$ The reports demonstrate that the $\pi$-conjugated $\mathrm{N}$-donor bridging ligands such as pyrazine and aromatic dicarboxylic acids acting as organic ligands have been extensively utilized in the preparation of coordination compounds. ${ }^{15-19}$

\footnotetext{
*For correspondence
}

Supramolecular architectures based on non-covalent interactions such as aromatic-aromatic stacking, donor-acceptor interactions and hydrogen bonding, are interesting and have attracted an enormous attention. In recent years, considerable effort has been made to understand the relationship between the molecular geometry and the crystal structure in terms of the prevalent hydrogen-bonding patterns. ${ }^{20}$ The various strong and weak hydrogen bonds have the powerful directional effect to organize individual molecules into supramolecular architectures as ribbons, rosettes, layers, tubes, rods, spheres and sheets. ${ }^{21}$ The electrochemical reactions catalyzed by transition metal complexes have also received significant attention during the past decades. ${ }^{22}$

Transition metal elements of ruthenium, iron, platinum, iridium, manganese, cobalt, tungsten, zinc and vanadium in different forms such as metals or metal oxide, metallocyanides and organometallic complexes have been successfully dispersed on some substrates such as carbon on conductive polymers to make catalysts. The immobilization of transition metal compound 
onto carbon nanotubes increased the catalytic activity of the modified surfaces. ${ }^{23-26}$ Due to this fact, we constructed a novel functional hybrid film of carbon nanotube and $\left[\mathrm{Cu}_{2}(\mathrm{pydc})_{2}(\mathrm{pz})\left(\mathrm{H}_{2} \mathrm{O}\right)_{2}\right](\mathrm{Cu}-\mathrm{PDAP})$ on a glassy carbon electrode as a catalytic layer for Lcysteine detection. Results show that $\mathrm{Cu}$-PDAP exhibits a remarkable electrocatalytic activity for oxidation of L-cysteine. The proposed sensor possesses high sensitivity and stability and so it has the promising future for practical application.

\section{Experimental}

\subsection{General methods and materials}

All materials were purchased from Merck. Solvents used throughout the reactions were of high purity. Multiwall carbon nanotubes with purity 95\% (10$20 \mathrm{~nm}$ diameters) and $1 \mu \mathrm{m}$ length were obtained from Nanolab (Brighton, MA). IR spectroscopy was performed on a Perkin-Elmer Spectrum RXI FT-IR spectrophotometer in the $4000-400 \mathrm{~cm}^{-1}$ region using a $\mathrm{KBr}$ pellet. The UV-Vis spectra were recorded on a JELWAY 6505 UV-Vis spectrophotometer and a Shimadzu 2100 spectrophotometer in the range of 200$900 \mathrm{~nm}$ at room temperature. Elemental analysis was performed with a Heraus CHN Pro apparatus. The X-ray data were obtained with a Bruker SMART ApexII diffractometer. Thermal analyses (TG-DTGDTA) including the thermogravimetery (TG), derivative thermogravimetery (DTG) and differential thermal analysis (DTA) were carried out using a Perkin Elmer simultaneous thermal analyzer (STA Pyris Diamond Model) with the heating rate of $10^{\circ} \mathrm{C} / \mathrm{min}$ in $\mathrm{N}_{2}$ atmosphere. Electrochemical experiments were performed via using a $\mu$ Autolab III (Eco Chemie B.V.) potentiostat/galvanostat by NOVA 1.8 software. A conventional three electrode cell was used with an $\mathrm{Ag} \mid \mathrm{AgCl}$ electrode $(\mathrm{KCl} 3 \mathrm{M})$ as the reference electrode, a Pt wire as counter electrode and a modified glassy carbon electrode (GCE) as working electrode. The cell was a one compartment cell with an internal volume of $10 \mathrm{~mL}$. JENWAY $\mathrm{pH}$ meter (model 3345) was used for $\mathrm{pH}$ measurements.

\subsection{Crystal structure determination and refinement}

Suitable crystals of the synthesized compound were selected for X-ray data collection. Unit cell determinations and data collections were carried out using a Bruker SMART Apex II CCD area detector system ${ }^{27}$ with Mo $\mathrm{K} \alpha$ radiation $(\lambda=0.71073 \AA)$. The structure was solved and refined by full-matrix least-squares techniques on $F^{2}$ using the programs SHELXS and SHELXL, respectively. ${ }^{28}$ Multi-scan absorption corrections were applied.

\subsection{Synthesis of $\left[\mathrm{Cu}_{2}(\text { pydc })_{2}(\mathrm{pz})\left(\mathrm{H}_{2} \mathrm{O}\right)_{2}\right] \cdot 2 \mathrm{H}_{2} \mathrm{O}(\mathbf{1})$}

An aqueous solution of $\mathrm{Cu}\left(\mathrm{NO}_{3}\right)_{2} \cdot 4 \mathrm{H}_{2} \mathrm{O} \quad(68 \mathrm{mg}$; $0.26 \mathrm{mmol})$ in water $(5 \mathrm{~mL})$ was added dropwise to a mixed ligand solution of pyridine-2,6-dicarboxylic acid $(100 \mathrm{mg} ; 0.59 \mathrm{mmol})$ and pyrazine $(47 \mathrm{mg} ; 0.59 \mathrm{mmol})$ in water $(20 \mathrm{~mL})$ under stirring in a 1:2:2 molar ratio, shown in scheme 1 . The solution was heated very slightly $\left(60^{\circ} \mathrm{C}\right)$ for $1 \mathrm{~h}$, then was placed into Teflon line a stainless steel autoclave and heated to $140^{\circ} \mathrm{C}$ for 3 days and slowly cooled to room temperature at a cooling rate of $3^{\circ} \mathrm{C}$ per minute. Small needles blue crystals of the complex were collected in $73 \%$ yield. Anal. Calc. for $\mathrm{C}_{18} \mathrm{H}_{18} \mathrm{Cu}_{2} \mathrm{~N}_{4} \mathrm{O}_{12}$ : C, 35.47; H, 2.98; N, 9.19\%. Found: C, 35.24; H, 2.92; N, 9.06\%. IR ( $\mathrm{KBr}$ disc, $v / \mathrm{cm}^{-1}$ ): 3403 (b), 3384(b), 3084(b), 1638(s), 1594(s), 1436 (s), 1400(s), 1372(s), 1122 (s), 1040(s), 891(s), 846(s), 762(s), 682(s), 593(s), 554(w), 445(s).

\subsection{Electrode modification}

To prepare a modified electrode, GCE was polished with emery paper followed by alumina (1.0 and $0.05 \mu \mathrm{m})$ and then thoroughly washed with twice distilled water. This electrode was afterwards placed in ethanol container and then an ultrasonic cleaning bath was used to remove the adsorbed particles. Then, $25 \mu \mathrm{L}$ solution of DMSO-CNTs $\left(0.4 \mathrm{mg} \mathrm{mL}^{-1}\right)$ was cast on the surface of GC electrode and dried in air to form a CNTs film at electrode surface. Afterwards, the electrode was thoroughly rinsed with water and

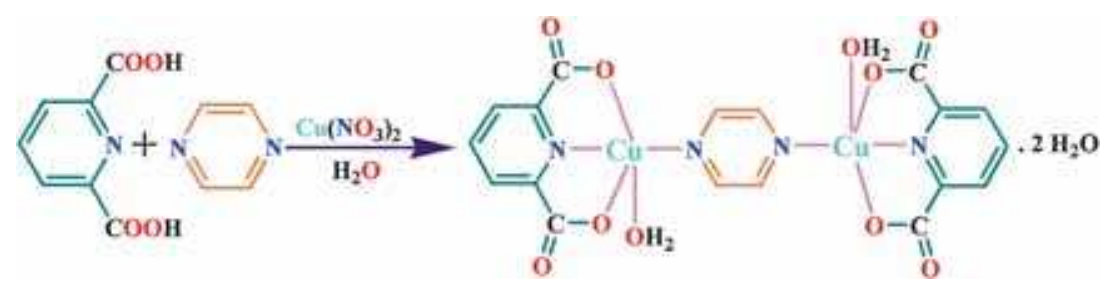

Scheme 1. Synthesis route of preparation $\left[\mathrm{Cu}_{2}(\mathrm{pydc})_{2}(\mathrm{pz})\left(\mathrm{H}_{2} \mathrm{O}\right)_{2}\right] \cdot 2 \mathrm{H}_{2} \mathrm{O}$. 
kept at room temperature for further use. The prepared CNTs/GC electrode was placed in DMSO solution with $0.1 \mathrm{M}$ tetrabuthyl ammonium perchlorate as the supporting electrolyte containing $1 \times 10^{-2} \mathrm{M} \mathrm{Cu}$-PDAP and the electrode potential was cycled between -0.5 and $0.7 \mathrm{~V}$ at a scan rate of $50 \mathrm{mV} \mathrm{s}^{-1}$ for 100 cycles. The modified electrode (denoted as Cu-PDAP/CNTs/GCE) was thoroughly rinsed and cycled between -0.5 and $0.7 \mathrm{~V}$ in $0.1 \mathrm{M}$ acetate buffer solution until a reproducible cyclic voltammogram (CV) was obtained.

\section{Results and Discussion}

\subsection{Synthesis and spectroscopic studies}

Treatment of $\mathrm{Cu}\left(\mathrm{NO}_{3}\right)_{2}$ with dipicolinic acid and pyrazine in 1:2:2 molar ratio under hydrothermal conditions gave compound $\mathbf{1}$ (scheme 1). The crystals were obtained by gradual cooling from $140^{\circ} \mathrm{C}$ to room temperature at a cooling rate of $3^{\circ} \mathrm{C}$ per minute. The obtained needles of blue crystals of compound $\mathbf{1}$ are stable in air and soluble in water, DMSO, DMF and $\mathrm{MeOH}$. Elemental analysis of the complex is entirely consistent with its determined composition by X-ray crystallography.

The IR spectrum of $\mathbf{1}$ exhibits the characteristic stretching bands of carboxylate groups between 1372 and $1638 \mathrm{~cm}^{-1}$. No strong absorption bands around $1700 \mathrm{~cm}^{-1}$ for $-\mathrm{COOH}$ are observed, demonstrating that carboxyl groups of organic moieties in $\mathbf{1}$ are completely deprotonated. The IR spectrum of compound 1 shows a broad band around $3403-3384 \mathrm{~cm}^{-1}$ due to $v(\mathrm{OH})$ stretching vibrations of water molecules. The band appears at around $1638 \mathrm{~cm}^{-1}$ due to the asymmetric stretching $\left(v_{\mathrm{as}}\right)$ of the carboxylate group; the symmetrical stretching $\left(v_{\mathrm{s}}\right)$ band of this group appears at $1372 \mathrm{~cm}^{-1}$. The value of $\Delta\left[v_{\mathrm{as}}-v_{\mathrm{s}}\right]$ is $266 \mathrm{~cm}^{-1}$, comparatively larger than $200 \mathrm{~cm}^{-1}$, indicating monochelation of the carboxylic group to the metal ion, ${ }^{29}$ which is in agreement with the X-ray crystal analysis.

The strong absorption bands at 1594 and $1435 \mathrm{~cm}^{-1}$ are attributed to the $v(\mathrm{C}=\mathrm{C})$ and $v(\mathrm{C}=\mathrm{N})$ vibrations in the ligands, respectively. ${ }^{30}$ The $v(\mathrm{C}-\mathrm{O})$ vibrations were observed at 1040 and $1272 \mathrm{~cm}^{-1}$, as indicated in literature. ${ }^{31-33}$ The ring wagging vibrations of the pyridine groups are also observed at 682 and $750 \mathrm{~cm}^{-1}$. The weak bands at 592 and $450 \mathrm{~cm}^{-1}$ are from the $\mathrm{Cu}-\mathrm{N}$ and $\mathrm{Cu}-\mathrm{O}$ vibrations, respectively, for complex 1 (figure $\mathrm{S} 1$ in Supplementary Information).

The electronic spectrum of $\mathbf{1}$ was recorded in solid state with $\mathrm{KBr}$ and in solution at room temperature (figure 1). The electronic spectrum reveals absorption bands below $320 \mathrm{~nm}$ with high molar extinction coefficients that can be assigned to $\pi \rightarrow \pi^{*}$ and $\mathrm{n} \rightarrow$ $\pi^{*}$ intra-ligand transitions. In the solid state absorption spectra of the complex, there are similar absorption peaks due to the $\pi-\pi^{*}$ and $n \rightarrow \pi^{*}$ transitions of ligands. The absorption band profiles in solution are similar to those absorption maxima of the complex $\mathbf{1}$ in the solid state. All the $\pi-\pi^{*}$ and $n \rightarrow \pi^{*}$ transition bands for the copper (II) complex in water, DMF, $\mathrm{MeOH}$ and DMSO are observed in the range $220-320 \mathrm{~nm}$. In the visible range, one broad peak was observed which can be assigned to $a_{1} \rightarrow b_{1}$ transition. ${ }^{34,35}$ The $d-d$ transitions show a similar pattern with the peak maximum at $780 \mathrm{~nm}$ in the solid state, $773 \mathrm{~nm}$ in water, $768 \mathrm{~nm}$ in DMF, $771 \mathrm{~nm} \mathrm{MeOH}$, and $781 \mathrm{~nm}$ in DMSO and suggest that the $\mathrm{Cu}$ (II) ion has the characteristics of a penta-coordinated copper complex with distortion (figure 1). ${ }^{36}$ All the data obtained from the electronic spectra in solutions do not show any noticeable differences from that of the solid state, so it may be assumed that the bonding modes of the ligands as well as the geometry of the complex do not change in solution state. ${ }^{37}$ The room temperature magnetic moment of the $\mathrm{Cu}$ (II) complex is $1.65 \mathrm{BM}$ per each $\mathrm{Cu}$ (II) ion in the crystal structure, demonstrating the presence of one unpaired electron in each cu(II) complex.
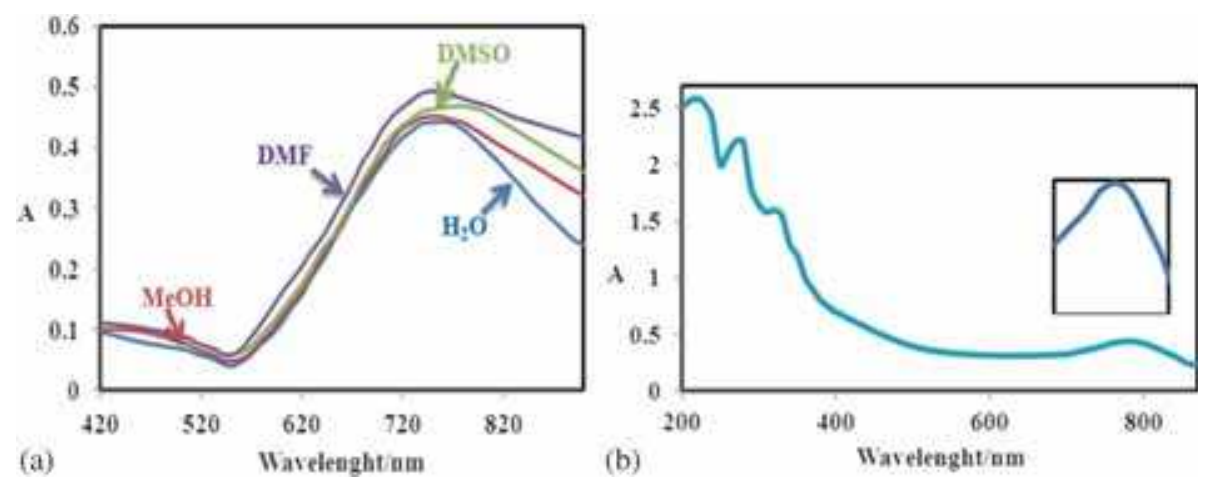

Figure 1. UV-Vis spectra of complex $\mathbf{1}\left(2.43 \times 10^{-3} \mathrm{M}\right)$ in solution (a), and (b) solid states. 
3.2 Crystal structure of $\left[\mathrm{Cu}_{2}(\mathrm{pydc})_{2}(\mathrm{pz})\left(\mathrm{H}_{2} \mathrm{O}\right)_{2}\right]$. $2 \mathrm{H}_{2} \mathrm{O}(\mathbf{1})$

The crystallographic data of $\mathbf{1}$ are summarized in table 1, selected bond lengths and angles as well as selected intermolecular hydrogen bond parameters are listed in tables 2 and 3, respectively. As shown in figure 2, compound $\mathbf{1}$ is a neutral dimeric structure

Table 1. Crystallographic data for compound $\mathbf{1 .}$

\begin{tabular}{lc}
\hline Crystal data & $\mathbf{1}$ \\
\hline Empirical formula & $\mathrm{C}_{18} \mathrm{H}_{14} \mathrm{Cu}_{2} \mathrm{~N}_{4} \mathrm{O}_{10} \cdot 2\left(\mathrm{H}_{2} \mathrm{O}\right)$ \\
Formula weight & 609.44 \\
Crystal system & Monoclinic \\
Space group & $P 2_{1} / n$ \\
$a, \AA$ & $5.7535(5)$ \\
$b, \AA$ & $15.3205(12)$ \\
$c, \AA$ & $11.9486(9)$ \\
$\beta,^{\circ}$ & $92.524(2)^{\circ}$ \\
$Z$ & 2 \\
$V, \AA^{3}$ & $1052.21(15)$ \\
$D$ calc/(Mg.m & -3 \\
$F(000)$ & 1.924 \\
Refl. collected & 616 \\
No. unique refl & 2610 \\
Goodness-of-fit on $F^{2}$ & $2346, R_{\text {int }}=0.024$ \\
$R_{1}[I>2 \sigma(I)]$ & 1.014 \\
$w R_{2}$ (all data) & 0.022 \\
\hline
\end{tabular}

consisting of two $\mathrm{Cu}(\mathrm{II})$ atoms, two (pydc) ${ }^{2-}$ ligands, one pyrazine ligand, two coordinated and two uncoordinated water molecules. We provide here a more detailed analysis of the solid-state packing and used it for preparation a modified electrode for electrochemical catalytic activities towards L-cysteine oxidation. As shown in figure 2, the tridentate (pydc) ${ }^{2-}$ ligand coordinates to $\mathrm{Cu}$ (II) uon in a meridional fashion and blocking three coordination sites of the square pyramid and the other two remaining sites were occupied by pyrazine as bridging ligand and one water molecule. Two such $\mathrm{Cu}(\mathrm{II})$ complexes are bridged by a pyrazine $\left(\mu_{2}\right)$ molecule through the equatorial coordination sites to form a dimer. The geometry of 5-coordinated compounds can be described either as a square pyramid or a trigonal bipyramidal with structural parameter $\tau(\tau=$ $\left.(\beta-\alpha) / 60^{\circ}\right)$, where $\beta$ and $\alpha$ are the largest angles in the coordination sphere, ${ }^{38}$ and its value is zero for a perfect square pyramid and one for a perfect trigonal bipyramid. The largest angles in 1, N1-Cu1-N2 and O1$\mathrm{Cu} 1-\mathrm{O} 3$ are $168.16(5)^{\circ}$ and $161.63(4)^{\circ}$ and resulting in $\tau=0.11$. Therefore, the geometry can be described as distorted square pyramidal. The polyhedron geometry of diaqua-bis(pyridine-2,6-dicarboxylato- $O, N$, $\left.O^{\prime}\right)$-( $\mu_{2}$-pyrazino)copper(II) dihydrate is illustrated in figure 2 .

Two planes of 2,6-pyridinedicarboxylate ligands in the dimeric complex are parallel and form an

Table 2. Selected bond distances $(\AA)$ and bond angles $\left(^{\circ}\right)$ for $\left[\mathrm{Cu}_{2}(\mathrm{pydc})_{2}(\mathrm{pz})\left(\mathrm{H}_{2} \mathrm{O}\right)_{2}\right] \cdot 2 \mathrm{H}_{2} \mathrm{O}$.

\begin{tabular}{lcccc}
\hline Cu1-N1 & & Bond lengths & & \\
$\mathrm{Cu} 1-\mathrm{N} 2$ & $1.8990(12)$ & & $\mathrm{Cu} 1-\mathrm{O} 1$ & $2.0102(11)$ \\
$\mathrm{Cu} 1-\mathrm{O} 5$ & $1.9656(12)$ & & $\mathrm{Cu} 1-\mathrm{O} 3$ & $2.0297(11)$ \\
& $2.1988(12)$ & & & \\
$\mathrm{N} 1-\mathrm{Cu} 1-\mathrm{N} 2$ & & & \\
$\mathrm{~N} 1-\mathrm{Cu} 1-\mathrm{O} 1$ & $168.16(5)$ & & & $91.63(4)$ \\
$\mathrm{N} 2-\mathrm{Cu} 1-\mathrm{O} 1$ & $81.45(5($ & $\mathrm{O} 1-\mathrm{Cu} 1-\mathrm{O} 3$ & $97.63(5)$ \\
$\mathrm{N} 1-\mathrm{Cu} 1-\mathrm{O} 3$ & $96.26(5($ & $\mathrm{N} 1-\mathrm{Cu} 1-\mathrm{O} 5$ & $93.31(5)$ \\
$\mathrm{N} 2-\mathrm{Cu} 1-\mathrm{O} 3$ & $80.64(5($ & $\mathrm{N} 2-\mathrm{Cu} 1-\mathrm{O} 5$ & $92.15(5)$ \\
\hline
\end{tabular}

Table 3. Selected hydrogen bond geometry for compound $\mathbf{1}$.

\begin{tabular}{|c|c|c|c|c|}
\hline $\mathrm{D}-\mathrm{H} \cdots \mathrm{A}$ & $(\mathrm{D}-\mathrm{H}) \AA$ & $(\mathrm{H} \cdots \mathrm{A}) \AA$ & $\mathrm{d}(\mathrm{D} \cdots \mathrm{A}) \AA$ & $(\mathrm{D}-\mathrm{H} \cdots \mathrm{A})\left({ }^{\circ}\right)$ \\
\hline $\mathrm{O} 5-\mathrm{H} 5 \mathrm{~A} \cdots \mathrm{O} 4^{\mathrm{i}}$ & $0.80(3)$ & $1.96(3)$ & $2.7534(16)$ & 168 \\
\hline $\mathrm{O} 5-\mathrm{H} 5 \mathrm{~B} \cdots \mathrm{O}^{\mathrm{ii}}$ & $0.79(3)$ & $1.94(3)$ & $2.7260(18)$ & 174 \\
\hline $\mathrm{O} 6-\mathrm{H} 6 \mathrm{~A} \cdots \mathrm{O} 2^{\mathrm{iii}}$ & $0.76(3)$ & $2.04(3)$ & $2.7956(17)$ & 171 \\
\hline 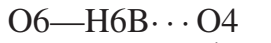 & $0.82(3)$ & $2.05(3)$ & $2.8681(17)$ & 177 \\
\hline $\mathrm{C} 3-\mathrm{H} 3 \cdots \mathrm{O} 2^{\mathrm{iv}}$ & $0.88(2)$ & $2.39(2)$ & $3.123(2)$ & 148 \\
\hline $\mathrm{C} 5-\mathrm{H} 5 \cdots \mathrm{O}^{\mathrm{v}}$ & $0.93(2)$ & $2.54(2)$ & $3.574(2)$ & 149 \\
\hline
\end{tabular}

Symmetry codes: (i) $x-1 / 2,-y+1 / 2, z+1 / 2$; (ii) $x-1, y, z$; (iii) $-x+1 / 2, y-1 / 2,-z+1 / 2$; (iv) $-x-1,-y+1,-z$; (v) $x-1 / 2,-y-1 / 2, z-3 / 2$. 


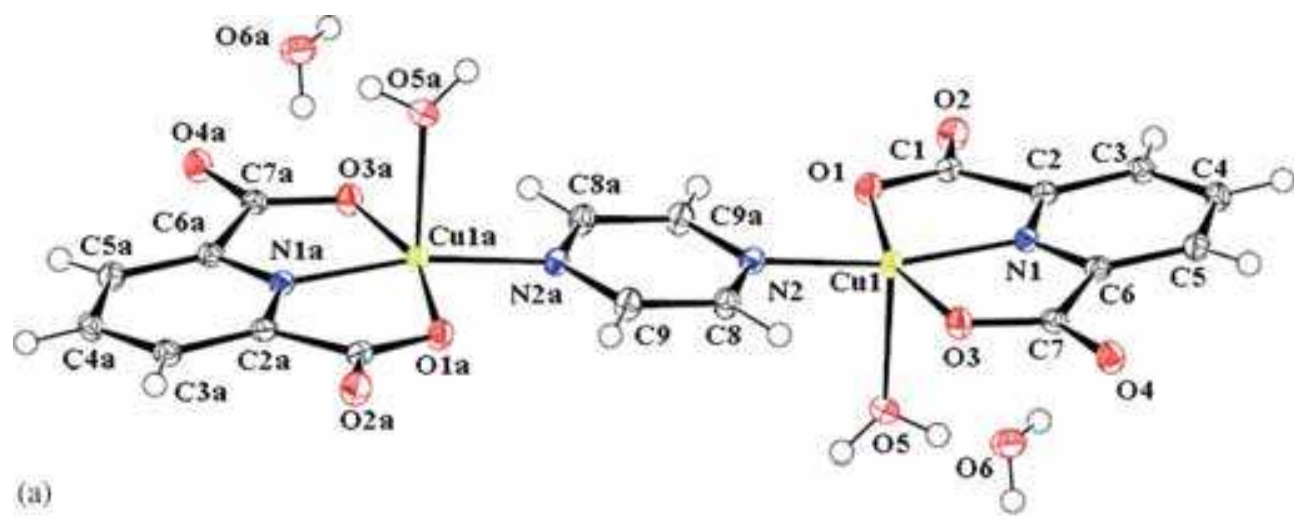

(a)

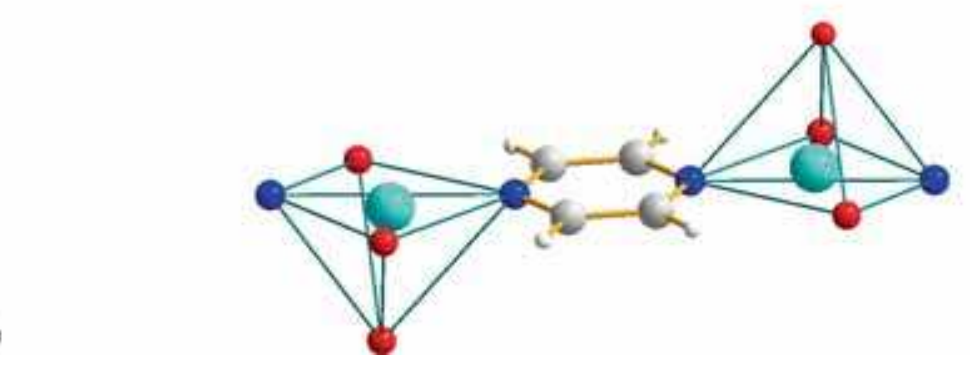

(b)

Figure 2. (a) Dimer structure of $\left[\mathrm{Cu}_{2}(\mathrm{pydc})_{2}(\mathrm{pz})\left(\mathrm{H}_{2} \mathrm{O}\right)_{2}\right] \cdot 2 \mathrm{H}_{2} \mathrm{O}$, Displacement ellipsoids are drawn at the $50 \%$ probability level. (b) Coordination environment of $\mathrm{Cu}$ (II) complex.

angle of approximately $12.29^{\circ}$ with the plane of pyrazine molecule (figure 3 ). In the crystal structure of $\mathbf{1}$, extensive network of hydrogen bonds exists between dimers and uncoordinated water molecules (figure 4).

As is shown in figure 5, the carboxyl groups of $(\text { pydc })^{2-}$ and water molecules are involved in intermolecular $\mathrm{O}-\mathrm{H} \cdots \mathrm{O}$ hydrogen bonding and form three types of robust hydrogen bond networks, namely, $R_{2}^{2}$ (8) I, $R_{3}^{2}$ (15) II and $R_{5}^{6}$ (24) III. These intermolecular interactions connected the dimeric complexes and water molecules into a 3D-network. In addition, two types of weak $\mathrm{C}-\mathrm{H} \cdots \mathrm{O}$ hydrogen bonds connected the neutral complexes to form 2D sheets. Another characteristic feature of this crystal structure is the presence of $\mathrm{C}-\mathrm{O} \cdots \pi$ interactions $[\mathrm{O} \cdots$ centroid distances $=3.477(13) \AA$ and 3.791(14) $\AA$ ] occur between
$\mathrm{C} 1-\mathrm{O} 2$ and $\mathrm{Cg} 3[\mathrm{Cg} 3=\mathrm{N} 1 / \mathrm{C} 2-\mathrm{C} 6]$ and $\mathrm{C} 7-\mathrm{O} 4$ and $\mathrm{Cg} 3$ (figure 5). The $\mathrm{O}-\mathrm{H} \cdots \mathrm{O}$ hydrogen bonds occur both within a stack of dimers along the crystallographic a-axis and between dimers of different stacks. Within a stack of dimers along the a-axis, the $\mathrm{O}-\mathrm{H} \cdots \mathrm{O}$ hydrogen bond is between a coordinated water oxygen atom in one dimer and an uncoordinated carboxylate oxygen atom in a neighboring dimer. This hydrogen bond (O5$\mathrm{H} 5 \mathrm{~A} \cdots \mathrm{O} 4)$ has a bond angle of $168^{\circ}$ and a distance of 2.753(16) $\AA$ between the two oxygen atoms. Interestingly, extension this kind of hydrogen bond interactions makes fascinating $2 \mathrm{D}$ porosity sheets as shown in figure 6 . The second type of $\mathrm{O}-\mathrm{H} \cdots \mathrm{O}$ hydrogen bond occurs between uncoordinated water molecules and uncoordinated carboxylate oxygen atoms of (pydc) ${ }^{2-}$ ligands and these water molecules are located in the cavities.

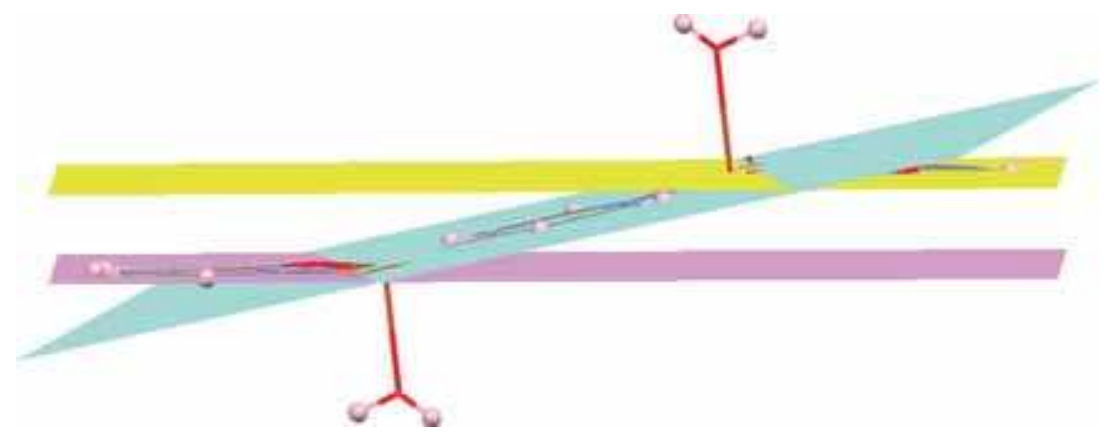

Figure 3. A view of different planes in $\mathrm{Cu}$ (II) complex. 


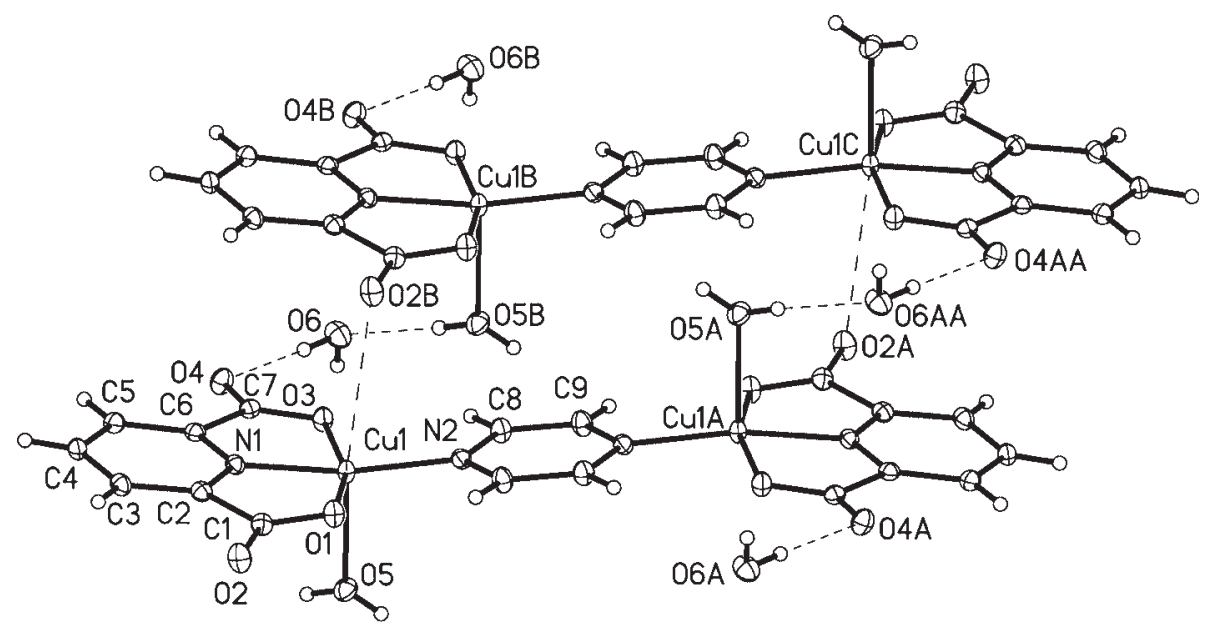

Figure 4. A view of hydrogen bond interactions in $\left[\mathrm{Cu}_{2}(\mathrm{pydc})_{2}(\mathrm{pz})\left(\mathrm{H}_{2} \mathrm{O}\right)_{2}\right] \cdot 2 \mathrm{H}_{2} \mathrm{O}$.

The $\mathrm{D} \cdots \mathrm{A}$ distance for this hydrogen bond (O6H6B ... O 4) is $2.868(17) \AA$ and its bond angle is $177^{\circ}$. The third $\mathrm{O}-\mathrm{H} \cdots \mathrm{O}$ hydrogen bond which incorporated in forming the cavities takes place between $\mathrm{O} 5$ H5B . . O6 with D ... A distance about 2.726 (18) A and $174^{\circ}$.

\subsection{Thermal analysis}

The thermal behavior of compound $\mathbf{1}$ was studied at room temperature to $1000^{\circ} \mathrm{C}$ in $\mathrm{N}_{2}$ atmosphere. The endothermic peak of 1 between 40 and $200^{\circ} \mathrm{C}$, correspond to loss of 4-moles of water molecules (found $11 \%$

(a)
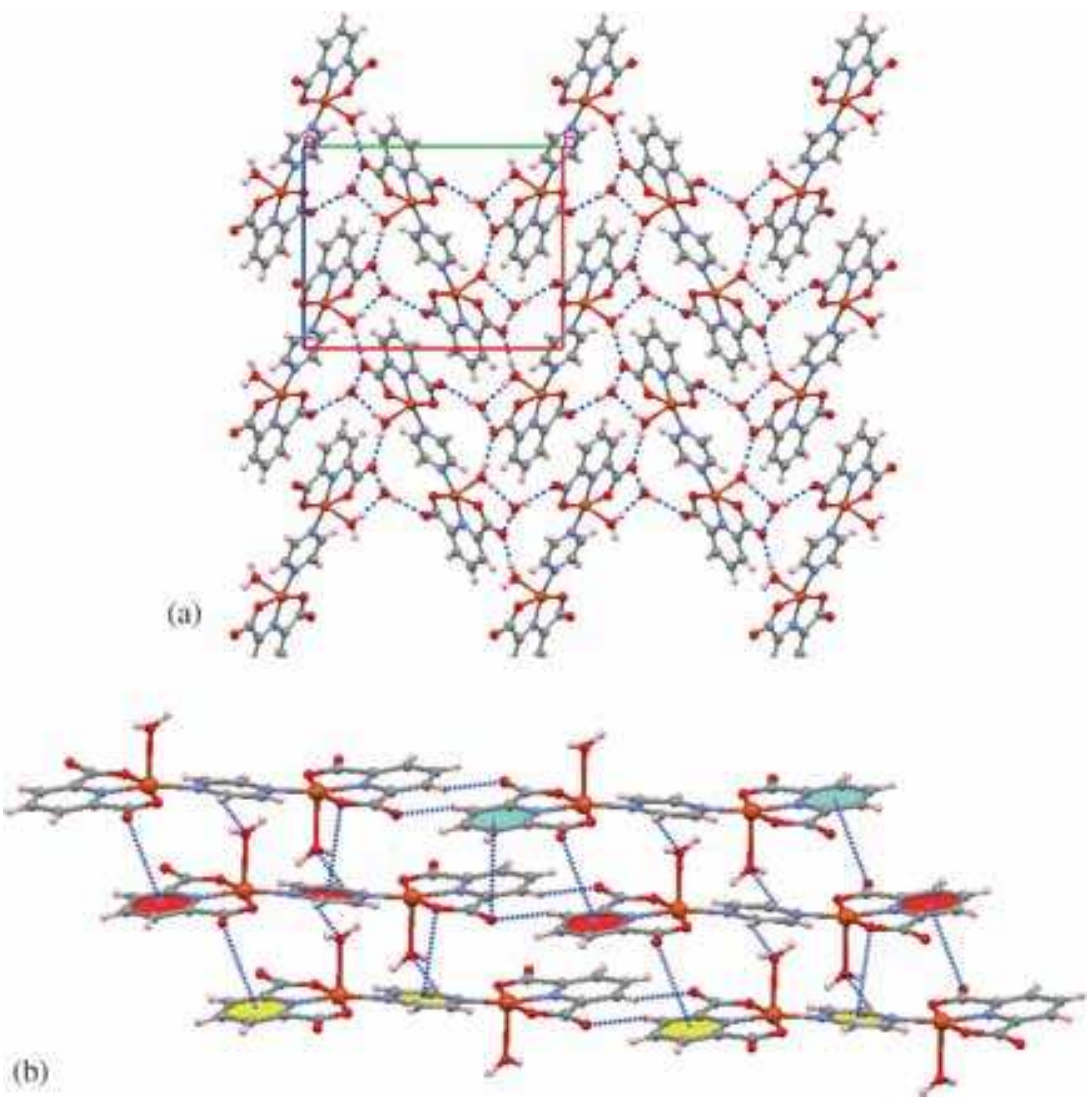

Figure 5. (a) The extended $2 \mathrm{D}$ network of compound $\mathbf{1}$ interconnected by $\mathrm{O}-\mathrm{H} \cdots \mathrm{O}$ hydrogen bonds, uncoordinated water molecules and neighboring stacks of dimers. (b) A view showing how the dimeric complexes are connected by $\mathrm{O}-\mathrm{H} \cdots \mathrm{O}, \mathrm{C}-\mathrm{H} \cdots \mathrm{O}$ and $\mathrm{C}-\mathrm{O} \cdots \pi$ interactions (blue dashed lines) to form $2 \mathrm{D}$ sheet. 


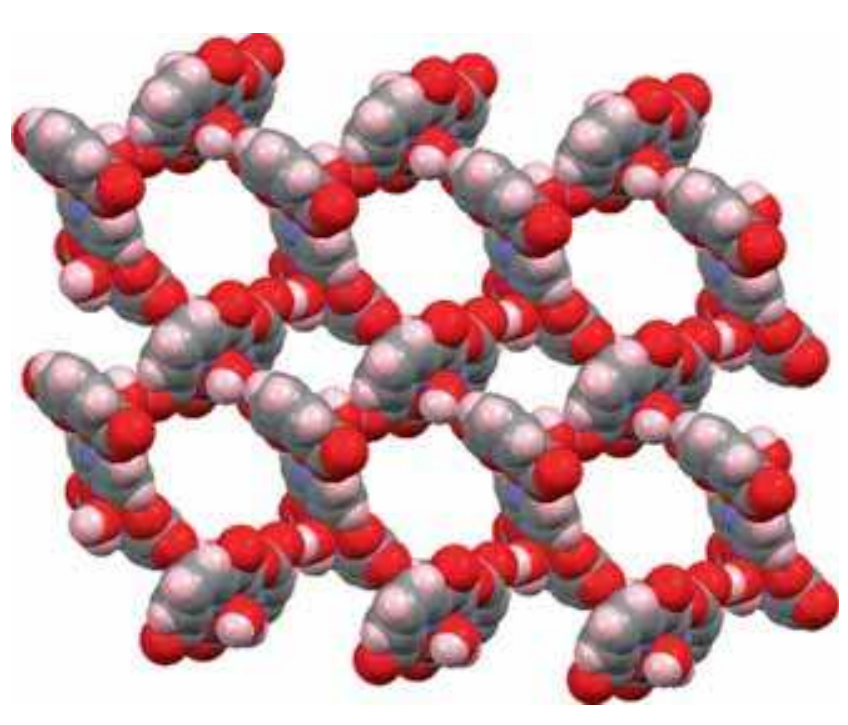

Figure 6. Porous network resulted from $\mathrm{O}-\mathrm{H} \cdots \mathrm{O}$ type interaction in the crystal lattice of $\mathbf{1}$.

and calc. $11.81 \%$ ). The TG curve shows that the complex starts to decompose with the gradual release the organic moiety. The final decomposition product was $\mathrm{CuO}$ (found $15.20 \%$, calc. $13.05 \%$ ).

\subsection{Properties of the $C u-P D A P / C N T s / G C$ electrode}

Electrodeposition of $\mathrm{Cu}$-PDAP at the surface of CNTs/GC electrode was carried out by immersion $C N T s / G C$ electrode in $1.0 \times 10^{-2} \mathrm{M} \mathrm{Cu}$-PDAP in DMSO-acetate buffer solutions with $0.1 \mathrm{M}$ tetrabuthyl ammonium perchlorate (figure $7 \mathrm{a}$ ). The potential was continuously cycled between -400 and $700 \mathrm{mV}$ at the potential sweep rate of $50 \mathrm{mV} \mathrm{s}^{-1}$. In the first cycle, a well-defined irreversible anodic peak appears at a potential of about $20 \mathrm{mV}$ that may be due to adsorption of Cu-PDAP and its oxidation product on the electrode surface (this anodic peak corresponding to PDAP oxidation) (figure $7 \mathrm{~b}$ ). This anodic peak disappeared in the next cycle and new anodic and cathodic peaks corresponding to $\mathrm{Cu}(\mathrm{II})$-PDAP / $\mathrm{Cu}$ (I)-PDAP appeared around 310 and $110 \mathrm{mV}$, respectively. Consecutive cyclic voltammograms showed that the thickness of Cu-PDAP film grows through each cycle during the electrodeposition of Cu-PDAP complex (figure 7a). The anodic and cathodic peak currents did not alter upon further potential cycling (more than 50 cycles).

The results show that not only the peak currents increase steadily with increasing the scan number but also their anodic and cathodic peaks potential shifted towards positive and negative values, respectively. These results confirm the continuous deposition of Cu-PDAP film at the electrode surface. The same results have been previously reported..$^{39,40}$ The redox reaction that occurs during cycles is related to the $\mathrm{Cu}(\mathrm{I})$ PDAP/ $\mathrm{Cu}$ (II)-PDAP transition. ${ }^{41}$ As can be seen in figure $7 \mathrm{a}$, the formal potential $\left(\mathrm{E}^{0^{\prime}}\right)$ is about $0.21 \mathrm{~V}$ versus the reference electrode and the difference between anodic and cathodic peak potential is about $96 \mathrm{mV}$.

To investigate the effect of PDAP on modification of the electrode, modified electrode was made from $0.1 \mathrm{M}$ tetrabuthyl ammonium perchlorate containing $\mathrm{CuCl}_{2}$ (a) and $\mathrm{Cu}-\mathrm{PDAP}$ (b) and the resulting electrodes were denoted as a $\mathrm{Cu} / \mathrm{CNTs} / \mathrm{GC}$ and $\mathrm{Cu}-\mathrm{PDAP} / \mathrm{CNTs} / \mathrm{GC}$, respectively (figure 8). As it is seen, a pair of illdefined redox peaks were observed when $\mathrm{Cu} / \mathrm{CNTs} / \mathrm{GC}$ electrode was used (curve a). On the other hand, a pair of well-defined redox peaks were observed when $\mathrm{Cu}-\mathrm{PDAP} / \mathrm{CNTs} / \mathrm{GC}$ electrode was used (curve b). So, there is a considerable enhancement in the charge of voltammogram in the presence of PDAP (about ten times).

It is well known that in aqueous media the oxidation of metal ions is very difficult that may be due
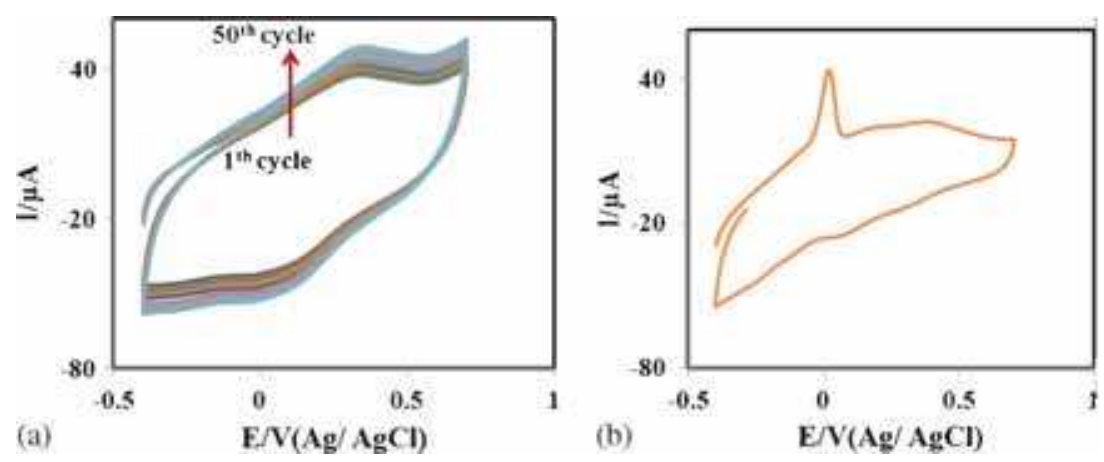

Figure 7. (a) Consecutive cyclic voltammograms of CNTs/GC electrode in $1.0 \times 10^{-2} \mathrm{M} \mathrm{Cu}$-PDAP in DMSO-acetate buffer solution with $0.1 \mathrm{M}$ tetrabuthyl ammonium perchlorate at a scan rate of $50 \mathrm{mVs}^{-1}$ (every five cycles).

(b) First cycle of CNTs/GC electrode in the same solution. 


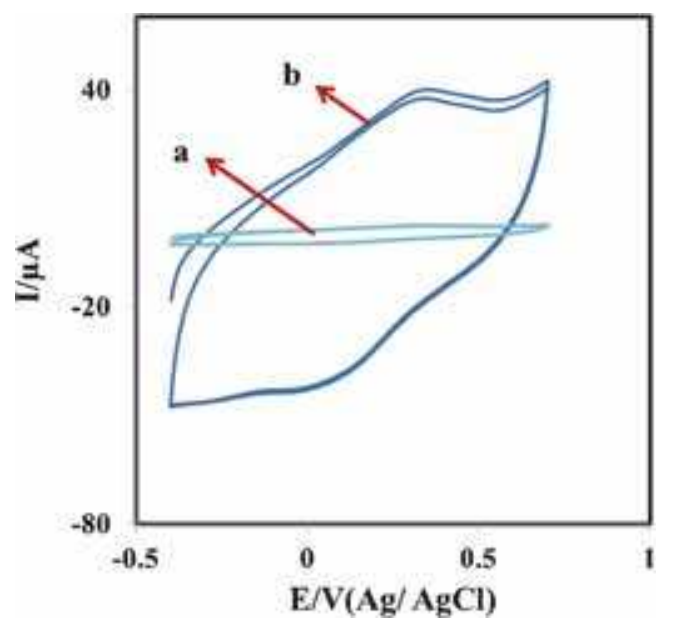

Figure 8. Cyclic voltammograms of $\mathrm{Cu} / \mathrm{CNTs} / \mathrm{GC}$ electrode (curve a), and $\mathrm{Cu}-\mathrm{PDAP} / \mathrm{CNTs} / \mathrm{GC}$ electrode (curve b), in $0.25 \mathrm{M}$ acetate buffer solution at a scan rate of $50 \mathrm{mVs}^{-1}$.

to the strong hydration of ions. ${ }^{42}$ Therefore, when copper ion is coordinated by PDAP, its oxidation conditions can be changed significantly and the $\mathrm{Cu}(\mathrm{I})$ $\mathrm{PDAP} / \mathrm{Cu}(\mathrm{II})-\mathrm{PDAP}$ redox couple is observed in the $\mathrm{Cu}$-PDAP film.

\subsection{Electrocatalytic oxidation of L-cysteine at $\mathrm{Cu}-\mathrm{PDAP} / \mathrm{CNT} \mathrm{s} / \mathrm{GC}$ electrode}

Application of the modified electrode for oxidation L-cysteine was evaluated by cyclic voltammetry. The cyclic voltammetric responses of GC, CNTs/GC, $\mathrm{Cu}-\mathrm{PDAP} / \mathrm{GC}$ and $\mathrm{Cu}-\mathrm{PDAP} / \mathrm{CNT} / \mathrm{GC}$ electrodes in $0.25 \mathrm{M}$ acetate buffer solution without and with Lcysteine in solution were studied (figure S2). The results show that, L-cysteine did not undergo oxidation at GC and CNTs/GC electrodes in the potential range of $-0.5-0.6 \mathrm{~V}$ (curves $b$ and $d$ ). When GC electrode was modified with $\mathrm{Cu}-\mathrm{PDAP}$ film $(\mathrm{Cu}-$ PDAP/GC) and then inserted into the same L-cysteinecontaining electrochemical cell, a small electrocatalytic activity was observed for L-cysteine oxidation (curve f). Modification of the GC electrode with multiwall carbon nanotube improved the electroactivity of $\mathrm{Cu}$ PDAP/CNTs/GC electrode for oxidation of L-cysteine (curve h). When Cu-PDAP film deposited on multiwall carbon nanotube was used as a modified electrode in the same solution a large anodic current was observed with a small cathodic counterpart. The observed current is associated with L-cysteine oxidation. Whereas L-cysteine was not oxidized at the surface of GC and CNT/GC electrodes, electroactivity toward L-cysteine on modified electrode (Cu-PDAP/CNTs/GC) was significant.

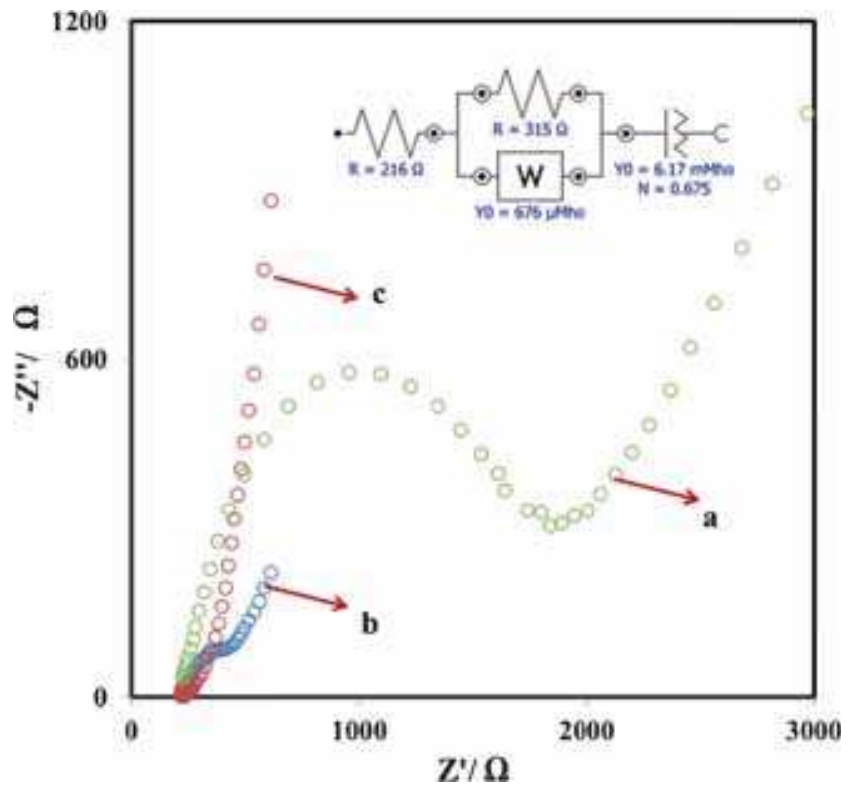

Figure 9. Nyquist plots of bare GC electrode (curve a), $\mathrm{Cu}-\mathrm{PDAP} / \mathrm{GC}$ (curve b), and Cu- PDAP/CNTs/GC (curve c) in $0.1 \mathrm{M} \mathrm{KCl}$ solution containing $5 \mathrm{mM}$ of L-cysteine. Inset: Equivalent circuit used to model impedance data in the presence of redox couples. Conditions: potential $=0.35 \mathrm{~V}$, frequency range of $10 \mathrm{kHz}-0.1 \mathrm{~Hz}, \mathrm{~A}=0.0534 \mathrm{~cm}^{2}$ and $\mathrm{pH}=6$.

Upon addition of L-cysteine, an enhancement in the anodic peak current was observed and the cathodic peak current tended to decrease. The reason for this increase is that, along with the anodic potential sweep, L-cysteine reduces $\mathrm{Cu}$ (II)-PDAP to $\mathrm{Cu}(\mathrm{I})$-PDAP, while simultaneous oxidation of the regenerated $\mathrm{Cu}(\mathrm{I})$-PDAP causes an increase in the anodic current. For the same reason, the cathodic current is smaller in the presence of L-cysteine, indicating that $\mathrm{Cu}(\mathrm{II})$-PDAP is consumed during a chemical step.

Taking into account all these observations, a possible mechanism of L-cysteine electrooxidation on $\mathrm{Cu}$ PDAP/CNTs/GC electrode may be as follows:

$$
\begin{gathered}
{\left[\mathrm{Cu}^{\mathrm{I}}-\mathrm{PDAP}\right]^{+}+\mathrm{e}^{-} \rightarrow\left[\mathrm{Cu}^{\mathrm{I}}-\mathrm{PDAP}\right]} \\
2\left[\mathrm{Cu}^{\mathrm{II}}-\mathrm{PDAP}\right]^{+}+2 \mathrm{CySH} \rightarrow 2\left[\mathrm{Cu}^{\mathrm{I}}-\mathrm{PDAP}\right] \\
+\mathrm{CyS}-\mathrm{SCy}+2 \mathrm{H}^{+}
\end{gathered}
$$

Such a behavior is indicative of an $\mathrm{EC}^{\prime}$ mechanism. On the other hand, the increased current in the oxidation region is due to the fact that the L-cysteine present in solution diffuses toward the electrode and reduces $\mathrm{Cu}$ (II)-PDAP which is produced electrochemically. As $\mathrm{Cu}$ (I)-PDAP is regenerated by L-cysteine during the potential sweep, there is a resultant increase in the anodic current.

Electrochemical impedance spectroscopy (EIS) technique has been proved as an effective method for 


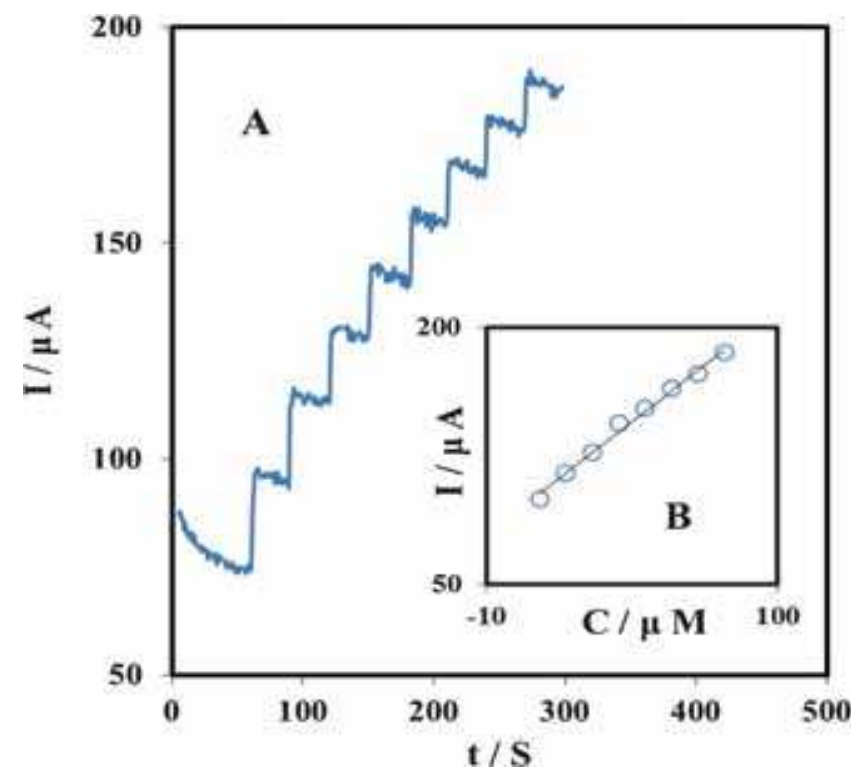

Figure 10. (A) Amperometric response of rotating sensor for successive addition of $10 \mu \mathrm{M}$ L-cysteine; conditions: potential $=0.35 \mathrm{~V}$ and rotating speed of $2000 \mathrm{rpm}$. (B) Plot of amperometric current vs. L-cysteine concentration.

probing the features of surface modified electrodes. To understand the electrochemical reactions at the different modified electrodes, the EIS experiments were performed in the presence of $5 \mathrm{mM}$ of L-cysteine. Figure 9 shows the typical Nyquest plots for bare GC, $\mathrm{Cu}-\mathrm{PDAP} / \mathrm{GC}$, and $\mathrm{Cu}-\mathrm{PDAP} / \mathrm{CNTs} / \mathrm{GC}$ in $0.1 \mathrm{M} \mathrm{KCl}$ solution containing $5 \mathrm{mM}$ of L-cysteine as an electrochemical redox marker. The straight line at low frequency is related to the diffusion process known as Warburg element, while the high frequency semicircle is related to the electron transfer resistance $\left(\mathrm{R}_{\mathrm{et}}\right)$, which controls the electron transfer kinetics of the redox probe at the electrode interface.

As can be seen in figure 9 for GC electrode, a semicircle is observed over the whole frequency region and the value of $R_{c t}$ is $315 \Omega$, indicating that the reaction is kinetically controlled (figure 9a). After immobilization of $\mathrm{Cu}$-PDAP at the surface of GC electrode, the value of $R_{c t}$ is significantly decreased to about $54 \Omega$ (figure 9b). The results indicate that the immobilized $\mathrm{Cu}$-PDAP decreases the charge transfer kinetics to about one-sixth of that at the bare GC electrode and it also confirmed that the presence of $\mathrm{Cu}$-PDAP film on GC electrode had a catalytic effect for oxidation of L-cysteine. For Cu-PDAP/CNTs/GC (figure 9c) electrode the calculated charge transfer resistance is less, which proves that the assembly of CNTs make the electron transfer easier. The deposition of CNTs on the surface of modified electrode facilitated the electron transfer of the electrochemical probe on the modified electrode.

\subsection{Amperometric detection of L-cysteine at the modified electrode}

Since amperometry under stirred conditions is more sensitive than cyclic voltammetry, it was used to estimate the lower limit of detection. Figure 10A displays a typical steady-state catalytic current-time response of the rotated modified electrode $(2000 \mathrm{rpm})$ with successive injection of $10 \mu \mathrm{M}$ L-cysteine, at a fixed potential of $0.35 \mathrm{~V}$ vs. reference electrode. As shown, during successive addition of L-cysteine, a well-defined response was observed, demonstrating stable and efficient catalytic ability of the Cu-PDAP immobilized on the multiwall carbon nanotube glassy carbon electrode.

The response current is linear in the range of 10 $80 \mu \mathrm{M}$ of L-cysteine (figure 10B). The calibration plot has a correlation coefficient of 0.998 and the detection limit of $2.1 \mu \mathrm{M}$ at signal to noise ratio of 3 . Detection limit and linear calibration range of the proposed modified electrode were compared with those previously reported, and the results are summarized in table 4. As can be seen, the analytical parameters are comparable or better than the results reported for L-cysteine determination at the surface of other modified electrodes (table 4).

\section{Conclusion}

$\mathrm{A} \mathrm{Cu}(\mathrm{II})$ dimer complex $\left[\mathrm{Cu}_{2}(\mathrm{pydc})_{2}(\mathrm{pz})\left(\mathrm{H}_{2} \mathrm{O}\right)_{2}\right] \cdot 2 \mathrm{H}_{2} \mathrm{O}$ has been synthesized and characterized. Neighboring dimers are connected to each other through extensive hydrogen bonding network. The layers of

Table 4. Electrochemical response for L-cysteine using various modified electrodes

\begin{tabular}{|c|c|c|c|}
\hline Electrode & Analyte & $\operatorname{LOD}(\mu \mathrm{M})$ & Linear range $(\mu \mathrm{M})$ \\
\hline MWCNTs-modified GCE ${ }^{43}$ & $\mathrm{CySH}$ & 5.4 & $10.0-500$ \\
\hline PolyN,Ndimethylaniline/ferrocyanide film/CPE ${ }^{44}$ & CySH & 6.38 & $7.40-138$ \\
\hline Ordered mesoporous carbon ${ }^{45}$ & $\mathrm{CySH}$ & 0.10 & $3.00-130$ \\
\hline Copper-cobalt hexacyanoferrate/CPE ${ }^{46}$ & $\mathrm{CySH}$ & 5.00 & $6.00-1000$ \\
\hline $\mathrm{Cu}-\mathrm{PDAP} / \mathrm{CNTs} / \mathrm{GC}$ & $\mathrm{CySH}$ & 2.10 & $10.0-80.0$ \\
\hline
\end{tabular}


complex are connected into a 3D supramolecular network by non-classical hydrogen bonds and $\mathrm{C}-\mathrm{H} \cdots \mathrm{O}$ stacking interactions. Also, the porosity of the crystal structure was formed by these kinds of intermolecular interactions. Oxidation of cysteine on the surface of modified electrode based on $\mathrm{Cu}$ (II) complex was investigated with cyclic voltammetry and electrochemical impedance spectroscopy (EIS) and the results showed that the $\mathrm{Cu}$-PDAP/CNTs film displays excellent electrochemical catalytic activity towards L-cysteine oxidation.

\section{Supplementary Information}

CCDC 1402561 contains the supplementary crystallographic data for $\mathbf{1}$. These data can be obtained free of charge at http://www.ccdc.cam.ac.uk/conts/retrieving. html, or from the Cambridge Crystallographic Data Center, 12 Union Road, Cambridge CB2 1EZ, UK (fax: 00441223336 033; e-mail: deposit@ccdc.cam.ac.uk). Supplementary Information is available at www.ias.ac. in/chemsci.

\section{References}

1. Yaghi O M, OKeeffe M, Ocking $\mathrm{N}$ W, Chae H K, Eddaoudi M and Kim J 2003 Nature 423705

2. Moulton B and Zaworotko M J 2001 Chem. Rev. 101 1629

3. Biradha K, Su C Y and Vittal J 2011 Cryst. Growth Des. 11875

4. Demessence A and Long J R 2010 Chem. Eur. J. 165902

5. Abrahams B F, Grannas M J, Hudson T A and Robson R 2010 Angew. Chem. Int. Ed. 491087

6. Ke X J, Li D S and Du M 2011 Inorg. Chem. Commun. 14788

7. Rao C N R and Natarajan S 2004 Angew. Chem. Int. Ed. 431466

8. Allendof M D, Bauer C A, Bhakta R K and Houk R J T 2009 Chem. Soc. Rev. 381330

9. Lee J Y, Farha O K, Roberts J, Scheidt K A, Nguyen S T and Hupp J T 2009 Chem. Soc. Rev. 381450

10. Murray L J, Dinca M and Long J R 2009 Chem. Soc. Rev. 381294

11. Kurmoo M 2009 Chem. Soc. Rev. 381353

12. Forster P M, Stock N and Cheetham A K 2005 Angew. Chem. Int. Ed. 447608

13. Zhou Y F, Lou B Y, Yuan D Q, Xu Y Q, Jiang F L and Hong M H 2005 Inorg. Chim. Acta 3583057

14. Chen S M, Lu C Z, Zhang Q Z, Liu J H and Wu X Y 2005 Eur. J. Inorg. Chem. 2423

15. Biswas R, Mukherjee S, Ghosh S, Diaz C and Ghosh A 2015 Inorg. Chem. Commun. 56108

16. Mahmudov K T, Haukka M, Sutradhar M, Mizar A, Kopylovich M N and Pombeiro A J L 2013 J. Mol. Struct. 1033127
17. Watanabe R, Shimada T, Koyama N, Ishida $\mathrm{T}$ and Kogane T 2011 Polyhedron 303165

18. Wriedt M and Zhou H C 2012 Dalton Trans. 414207

19. Ene C D, Lungu A, Mihailciuc C, Hillebrand M, C R P and M Andruh 2012 Polyhedron 31 539; (b) Zhang T, Wang D F, Huang R B and Zheng L S 2015 Inorg. Chim. Acta 427299

20. Thomas R and Kulkarni G U 2008 J. Mol. Struct. 873 160

21. Perpétuo G J and Janczak J 2008 J. Mol. Struct. 891 429

22. Lu B Y, Li H, Deng H, Xu Z H, Li W S and Chen H Y 2008 J. Electroanal. Chem. 62197

23. Li J, Yu Q and Peng T 2005 Anal. Sci. 21377

24. Sun X, Li R, Villers D, Dodelet J P and Desilet S 2003 Chem. Phys. Lett. 37999

25. Dai X, Wildgoose G G and Compton R G 2006 Analyst 131901

26. Ozoemena K I, Nyokong T, Nkosi D, Chambrier I and Cook M J 2007 Electrochim. Acta 524132

27. Programs Apex 2 and SAINT 2009 (Madison, Wisconsin, USA: Bruker AXS Inc.)

28. Sheldrick G M 2008 Acta Crystallogr. A64 112

29. Derikvand Z, Bruno G, Amiri Rudbari H, Shokrollahi A, Zarghampour F and Azadbakht A 2014 Inorg. Chim. Acta 410221

30. Kirillova M V, Da Silva M F C G, Kirillov A M, Da Silva J J R F and Pombeiro A J L 2007 Inorg. Chim. Acta 360506

31. Vargova Z, Zeleoak V, Cisaova I and Györyova K 2004 Thermochim. Acta 423149

32. Mao L, Wang Y, Qi Y, Cao M and Hu C 2004 J. Mol. Struct. 688197

33. Uçar I, Karabulut B, Bulut A and Büyükgüngör O 2007 J. Mol. Struct. 834-836 336

34. Cotton FA 1980 In Advanced Inorganic Chemistry (New York: Wiley-Interscience) p. 642

35. Derikvand Z, Talei G R, Aghabozorg H, Olmstead M M, Azadbakht A, Nemati A and Attar Gharamaleki J 2010 Chin. J. Chem. 282167

36. Kroczewska D, Kurzak B and Jezierska J 2006 Polyhedron 25678

37. Ghosh M, Majee A, Nethaji M and Chattopadhyay T 2009 Inorg. Chim. Acta $\mathbf{3 6 2} 2052$

38. Tabatabaee M, Bordbar M, Ghassemzadeh M, Tahriri M, Tahrir M, Mehri L Z and Neumüller B 2013 Eur. J. Med. Chem. 70364

39. Ciszewski A, Milczarek G, Lewandowska B and Krutowski K 2003 Electroanalysis 15518

40. Vilas-Boas M, Freire C, Castro B and Hillman A R 1998 J. Phys. Chem. B 1028533

41. Salimi A, Korani A, Hallaj R, Khoshnavazi R and Hadadzadeh H 2009 Anal. Chim. Acta 63563

42. Ciszewski A 1995 Electroanalysis 71132

43. Salimi A and Hallaj R 2005 Talanta 66967

44. Ojani R, Raoof J B and Zarei E 2010 J. Electroanal. Chem. 638241

45. Ndamanisha J C, Bai J, Qi B and Guo L 2009 Anal. Biochem. 38679

46. Abbaspour A and Ghaffarinejad A 2008 Electrochim. Acta $\mathbf{5 3} 6643$ 